\title{
Pulse Width Modulation Analysis of Five-Level Inverter- Fed Permanent Magnet Synchronous Motors for Electric Vehicle Applications
}

\author{
Omokhafe J. Tola a,1, ${ }^{*}$, Edwin A. Umoh b,2, Enesi A. Yahaya c,3 \\ a,c Department of Electrical and Electronic Engineering, Federal University of Technology, Minna, Nigeria \\ ${ }^{\mathrm{b}}$ Department of Electrical and Electronic Engineering Technology, Federal Polytechnic, Kaura Namoda, Nigeria \\ 1 omokhafe@gmail.com; ${ }^{2}$ eddyumoh@gmail.com; ${ }^{3}$ enesi.asizehi@ futminna.edu.ng \\ * Corresponding Author
}

ARTICLE INFO

Article history

Received 16 October 2021

Revised 19 November 2021

Accepted 21 November 2021

Keywords

Electric vehicle;

Inverter;

Permanent magnet synchronous motor;

Pulse width modulation

\begin{abstract}
In recent times, intense research has been focused on the performance enhancement of permanent magnet synchronous motors (PMSM) for electric vehicle (EV) applications to reduce their torque and current ripples. Permanent magnet synchronous motors are widely used in electric vehicle systems due to their high efficiency and high torque density. To have a good dynamic and transient response, an appropriate inverter topology is required. In this paper, a five-level inverter fed PMSM for electric vehicle applications, realized via co-simulation in an electromagnetic suite environment with a reduced stator winding current of PMSM via the use of in-phase disposition (PD) pulse width modulation (PWM) techniques as the control strategy is presented. The proposed topology minimizes the total harmonic distortion (THD) in the inverter circuit and the motor fed and also improves the torque ripples and the steady-state flux when compared to conventional PWM techniques. A good dynamic response was achieved with less than $10 \mathrm{~A}$ stator winding current, zero percent overshoot, and 0.02 second settling time synchronization. Thus, the stator currents are relatively low when compared to the conventional PWM. This topology contribution to the open problem of evolving strategies that can enhance the performance of electric drive systems used in unmanned aerial vehicles (UAV), mechatronics, and robotic systems.
\end{abstract}

This is an open-access article under the CC-BY-SA license.

\section{Introduction}

An electric vehicle (EV) is a major solution to environmental problems caused by conventional vehicles using fossil fuel due to their utilization of renewable energy sources and are tagged for future mobility. Extensive research has focused on improving the performance of electric motors used in EV applications for optimal energy utilization, and multilevel (ML) inverter-fed provides a quick torque and speed response with a good dynamic performance. A high proportion of electric vehicles uses electric motors with high torque and efficiency as a major selling point. Electric vehicle manufacturing companies like Toyota Prius, Chevrolet Bolt, 
Ford, Nissan, Honda Accord, and BMW electric car are known to use PMSM for their propulsion [1].

During the last few years, power electronics inverters have played a crucial role in the production of uninterruptible power supplies (UPS), variable frequency drives, high voltage DC transmission, induction heating EV drives, and DC source utilization [2]-[4]. And the development of modern power electronics devices with efficient performance in inverter-fed devices has multiplied [5]-[7]. When AC loads are fed through inverters, the desired voltage output magnitude and frequency could be attained in an effective way [8].

Permanent magnet synchronous motor has received attention among researchers due to its strategic importance in the modeling and design of electrical, electronics, mechanical and mechatronic systems. The permanent magnet synchronous motor (PMSM) as an AC machine is of profound interest for industrial applications due to its high efficiency, high torque density (torque to inertia ratio), and high-power density [9]-[11]. Recent research has extended the applications of chaos theory into the modeling of PMSM due to its dynamic characteristics, which possess similar characteristics to chaotic dynamics, and this holds a promising future for its application in robotics and unmanned vehicles [12]-[14]. The stable operation of PMSM and its dynamic characteristics are also essential requirements for industrial applications and have also received huge attention during the last decade [15]. Modern AC drives are controlled by different PWM techniques, and the power conversion of the AC - AC can be achieved by using different topologies. In recent times, Matrix converter and multilevel (ML) inverters have also drawn attention in the field of variable speed drives due to their enhanced static and dynamic responses, decreased THD, wide range of speed control, and ability to eliminate torque ripples. Recently, multilevel inverters have been convoluted in medium and high drives designs. The multilevel inverter has a reduced amount of voltage stress, fewer voltage harmonics, and electromagnetic interferences (EMI) on power electronics converters. The function of multilevel inverter in drives application is essential to generate a sinusoidal voltage out of several levels [16][17][18].

The applications of multilevel inverters are fast-growing in the industrial manufacturing sector due to their numerous advantages, which include the ability of its staircase waveforms to not only establish a better harmonic profile but equally minimizes $d v / d t$ stresses, reduced common-mode voltage, small voltage stress when compared to the overall operating voltage of the semiconductor devices. It also has input current with low distortion, making it possible for a renewable energy source to be easily interfaced [19]. The torque ripples produced by the PMSM and the harmonics content of the stator current are caused by the non-ideal sinusoidal shape of the inverters. The closer the inverter output voltage converges to an ideal sinusoidal shape, the lower would be the torque ripples and the harmonics contents. Torque ripples and harmonics content are less frequent in multilevel inverters than in the conventional three-level inverters during loading. Multilevel inverters are used to study desired performance during loading with input sully voltage. The occurrence of higher frequencies is involved in the conventional PWM techniques because of the unwanted harmonics at higher frequencies, which can simply be filtered. Thus numerous $\mathrm{kHz}$ can be achieved that is above the acoustic noise level. However, additional filters in the conventional PWM techniques can cause EMI, which eventually results in a change in the voltage $(d v / d t)$. A high $d v / d t$ produces common-mode voltages across the windings of the electric motor, which could result in damages. Therefore, cascaded multilevel inverter-based speed control could overwhelm the above-mentioned deficiencies in industrial motor drives.

A five-level cascaded H-bridge multilevel inverter using multicarrier pulse width modulation technique was proposed in [20], and the results show that the THD was reduced. The inverter also provided a higher output quality with relatively low power loss when compared to other conventional inverters of the same output quality. In [21], the researchers applied mathematical theory to develop a phase disposition pulse width modulation (PD-PWM) 
technique. A sinusoidal pulse width modulation (SPWM) technique which proved that harmonics contents could be reduced when combined both with and without an OTT filter, was implemented in [22]. Generally, a five-level cascaded H-bridge asymmetrical multilevel inverter topology requires eight switches. However, a multilevel inverter that utilized only six switches for the same multilevel was achieved in [23]. A topology with PI and Fuzzy control based on a novel configuration of switches for H-bridge ML to give five voltage levels was reported in [24]. In the study, two H-bridges were combined in spilled mode to offer an output of a nine-level inverter. The study proposed a multicarrier-based level shifting phase disposition PWM (LS-PDPWM) technique aimed to reduce the percentage of THD. The CHB inverter was overseen with proportional-integral (PI) and Fuzzy Logic Controller (FLC) to decrease the THD. Several other authors have studied the characteristics of inverters using different design and control strategies. In [25], a five-level cascaded H-bridge multilevel inverter based on pulse width modulation, in-phase and alternate phase opposition deposition techniques were presented. This kind of inverter allows high power quality with low output harmonics and lower commutation losses when compared to their conventional counterparts. A transformer-less MOSFET inverter with different pulse width modulations, suitable for applications in grid-tied photovoltaic systems, was presented in [26]. In [27], a modified SEPIC and three-level NPC inverter were applied in commutation torque ripple reduction in BLDC motors. A hysteresis current-controlled multilevel inverter-fed PMSM drive was analyzed and designed in [28].

The multilevel inverter-fed systems reported in the literature resulted in less harmonic distortion and reduced torque ripple in the motor. However, the ripple torque generally comes from two different sources. The cogging ripple torque is due to the interaction of the rotor magnetic flux and the angular variation in the stator magnetic reluctance. An efficient approach to reduce the cogging ripple torque is by skewing, which may be done on the stator and the rotor. Skewing reduces the ripple torque effectively. However, it is complicated and may increase the manufacturing cost.

In this study, the skewing to the motor is properly accounted for in the co-simulation with the electromagnetic suite environment. Accordingly, this study presents a five-level inverter that is used to drive a PMSM by co-simulation in an electromagnetic suite environment. This approach reduces the complexity and cost of implementation when compared to conventional approaches. An In-phase disposition PWM with less harmonic distortion is used with the fivelevel inverter as a control technique which results in reduced torque ripples and stator winding current of the PMSM. As an open problem in PMSM development, the research contribution of this study is the possibility of application of the topology to enhance the performance of electric drive systems used in unmanned aerial vehicles (UAV), mechatronics, and robotic systems.

\section{Methods}

In this section, the proposed topology and modulation techniques and operation of the designed topology are presented.

\subsection{In-Phase Disposition SPWM Control Scheme for a Five-level Inverter}

The proposed topology is a three-phase cascaded multilevel inverter (five-level). The proposed topology is shown in Fig. 1. This is based on the cells cascade connection of full-bridge with isolated DC source, and each cell provides two voltage levels, and the number of levels generated in the output voltages depends on the number of cells.

The number of levels $(n)$ generated in the output voltage depends on the number of cells $(k)$ and is expressed as:

$$
n=2 k+1
$$

Where $k$ is the number of $\mathrm{H}$-bridges for each phase. 


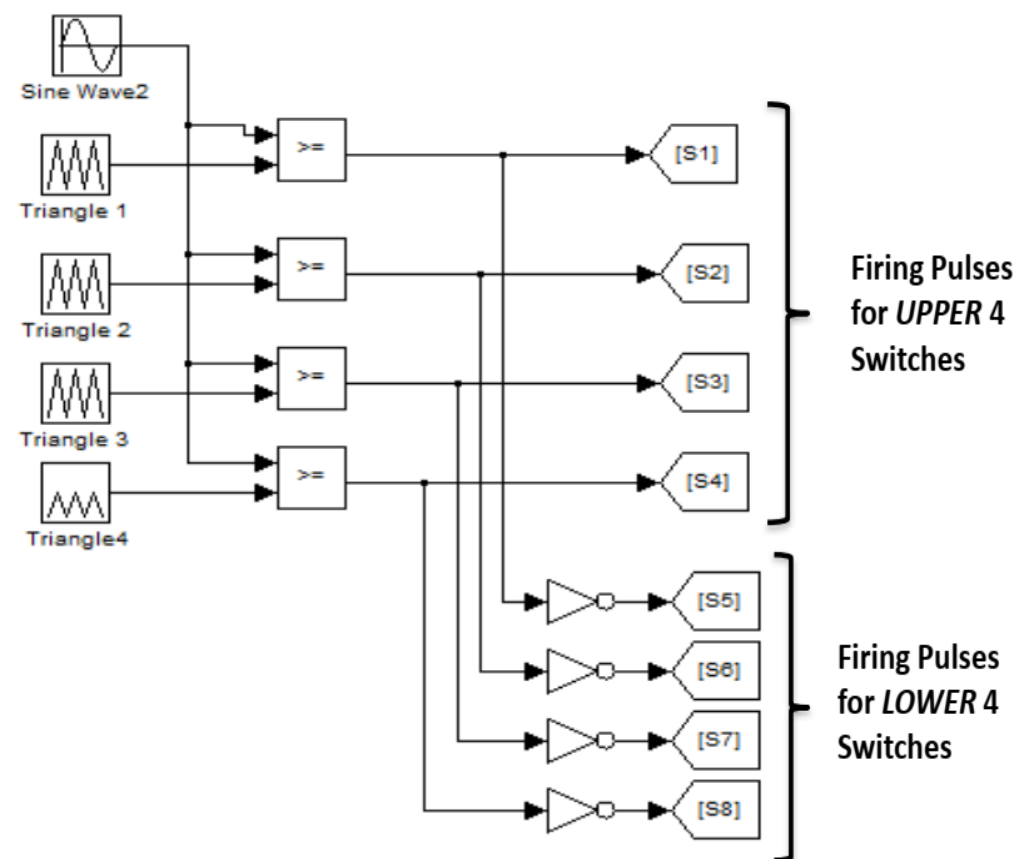

Fig. 1. MATLAB/Simulink model of the five-level PD SPWM

A five-level, three-phase inverter converts the DC voltages into three-phase AC voltages. In which its output voltages have five levels of AC voltages expressed by $V, V / 2,0$ and $-V,-V / 2$, consequently known as a five-level inverter.

\subsection{Sinusoidal Pulse Width Modulation Technique}

The sinusoidal PWM technique matched the carrier wave of frequency $\left(f_{c}\right)$ and the fundamental frequency $\left(f_{r}\right)$ of the sinusoidal modulating wave and the points of intersection define the switching points of the inverter. This can be classified according to carrier modulating signals. The multiple carrier-based SPWM are classified as in-phase disposition (PD), phase opposition disposition (POD), and alternative phase opposition (APO). In this study, PD is adopted for the three-phase five-level inverter. The vital constraints of the design procedures are the amplitude modulation index and frequency modulation index, which are respectively expressed as:

$$
\begin{gathered}
M_{a}=\frac{V_{r}}{V_{c}} \\
M_{f}=\frac{f_{r}}{f_{c}}
\end{gathered}
$$

where $V_{r}$ is the amplitude of the reference control signal and $V_{c}$ is the amplitude of the triangular carrier signal. $f_{c}$ is the frequency of the carrier wave, and $f_{r}$ is the frequency of the reference signal. The relationship for the generation of triangular carrier waves using the PD modulation technique is given by:

$$
M_{f}=22\left(\frac{f_{r}}{f_{c}}\right)
$$

where the triangular cycle waves are 22 for each cycle of existing sine wave given respectively as: 


$$
\begin{array}{r}
T_{s}=\frac{1}{f_{c}} \\
x=\frac{T_{s}}{4}
\end{array}
$$

Where $x$ is time in seconds.

The five-level PWM level-shifted waveforms can be generated by comparing the three reference control signals with the four triangular carrier waves. The MATLAB/Simulink model used for waveform generation is shown in Fig. 1, while a comparison of the carrier and reference signals of the three-phase is shown in Fig. 2. The output voltage is expressed as:

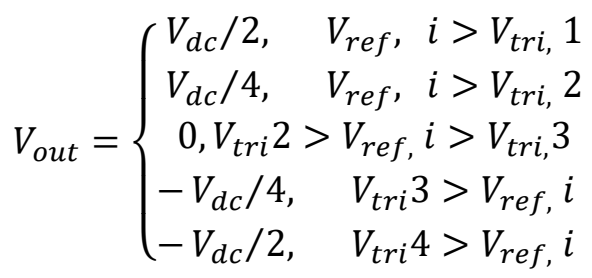

Where $i$ is phased $a, b$ or $c$.

\subsection{The Operation of the Five-level Cascaded H-Bridge Inverter}

The output voltage is obtained by adding the voltages bred by different modules. Each leg of the inverter is composed of a one-phase full-bridge that is linked to the load. The output voltages of each bridge can be fall within the range of $2 V_{d c}, V_{d c}, 0,-V_{d c}$ and $-2 V_{d c}$. The switching sequence of a five-level inverter is shown in Table 1.

Table 1. Switching States of the Five-level cascaded H-Bridge Inverter

\begin{tabular}{ccccccccc}
\hline \multicolumn{3}{c}{ The Upper Cell } & \multicolumn{5}{c}{ The Lower Cell } & $\begin{array}{c}\text { Output } \\
\text { Voltage (V) }\end{array}$ \\
\cline { 1 - 6 } S1 & S2 & S3 & S4 & S1 & S2 & S3 & S4 & 2Vdc \\
High & Low & Low & High & High & Low & Low & High & Vdc \\
High & High & Low & Low & High & Low & Low & High & Vdc \\
High & Low & Low & High & Low & Low & High & High & Vdc \\
High & Low & Low & High & High & High & Low & Low & Vdc \\
Low & Low & High & High & High & Low & Low & High & 0 \\
High & High & Low & Low & High & Low & Low & Low & 0 \\
High & High & Low & Low & Low & High & High & High & 0 \\
High & Low & Low & High & Low & High & High & Low & 0 \\
Low & High & High & Low & High & Low & Low & High & 0 \\
Low & Low & High & High & High & High & Low & Low & 0 \\
Low & Low & High & High & Low & Low & High & High & 0 \\
Low & High & High & Low & High & High & Low & Low & -Vdc \\
Low & Low & High & High & Low & High & High & Low & -Vdc \\
Low & High & High & Low & Low & Low & High & High & -Vdc \\
High & High & Low & Low & Low & High & High & Low & -Vdc \\
Low & High & High & Low & Low & High & High & Low & -2 Vdc \\
\hline
\end{tabular}

\section{Modelling of the three-phase PMSM}

The dynamics of the PMSM model are derived in order to understand the control scheme. The model is assumed to have a negligible permeability, saturation effect, and the flux density 
is assumed to be radial [29][30]. The dynamic model in the $d-q$ reference frame voltage and flux linkage of PMSM can be expressed as:

$$
\left\{\begin{array}{l}
V_{d}=r i_{d}+\frac{d}{d t} \lambda_{d}-\omega \lambda_{q} \\
V_{q}=r i_{q}+\frac{d}{d t} \lambda_{q}-\omega \lambda_{d}
\end{array}\right.
$$

Where the $d-q$ flux linkage of the three stator windings are expressed as

$$
\left\{\begin{array}{c}
\lambda_{d}=L_{d} i_{d}+\lambda_{p m} \\
\lambda_{q}=L_{q} i_{q}
\end{array}\right.
$$

Where the $\lambda_{d}, \lambda_{q}$ are the $d-q$ axis inductances of the stator winding and $\lambda_{p m}$ is the rotor magnetic flux linkage. The electrical torque, expressed in qd0 rotor reference frame by neglecting the harmonics and zero-sequence components, are expressed as:

$$
\begin{gathered}
T_{e}=\left(\frac{3}{2}\right)\left(\frac{P}{2}\right)\left(\lambda_{m}^{r} i_{q s}^{r}++\left(L_{d}-L_{q}\right) i_{q s}^{r} i_{d s}^{r}\right) \\
T_{e}=J\left(\frac{2}{p}\right) p \omega_{r}+B_{m}\left(\frac{2}{p}\right) \omega_{r}+T_{L}
\end{gathered}
$$

The expression (11) described the mechanical model of the motor, where $J$ is the inertia, $B_{m}$ is a damping coefficient and $\omega_{r}$ is rotor speed. The expression can be rewritten as a two-coupled first-order equation as given in (12) and was used to simulate the model using the PMSM parameters given in Table 2 .

$$
\left\{\begin{array}{c}
p \omega_{r}=\frac{T_{e}-T_{L}-B_{m} \omega_{r}}{J} \\
\theta_{r}=\int \omega_{r} d t
\end{array}\right.
$$

Table 2. Parameters of the PMSM

\begin{tabular}{lc}
\hline \multicolumn{1}{c}{ Parameters } & Values \\
\hline Stator Resistance $\left(R_{s}\right)$ & $1.6 \mathrm{Ohm}$ \\
Direct axis inductance $\left(L_{d}\right)$ & $0.006365 \mathrm{H}$ \\
Quadrature axis inductance $\left(L_{q}\right)$ & $0.006365 \mathrm{H}$ \\
Flux & $0.1852 \mathrm{~Wb}$ \\
Inertia () & $0.0001854 \mathrm{Kgm} 2$ \\
Friction coefficient $(B)$ & $5.39 \mathrm{e}-05$ \\
No. of Poles $(P)$ & 4 \\
\hline
\end{tabular}

\section{Numerical Simulation Results}

The model was developed and co-simulated in the electromagnetic suite (ANSYS MAXWELL) and MATLAB/SIMULINK to validate the effectiveness of the proposed scheme for PMSM. Fig. 2 shows a comparison of the three-carrier signal and the three-reference signal for the five-level inverter. The output voltage of a three-phase five-level inverter fed PMSM using PD PWM techniques for a period of $1 \mathrm{~ms}$ and amplitude of $20 \mathrm{~V}$ is shown in Fig. 3. The Fast Fourier Transform (FFT) analysis is shown in Fig. 4 with $35.24 \%$ THD. 


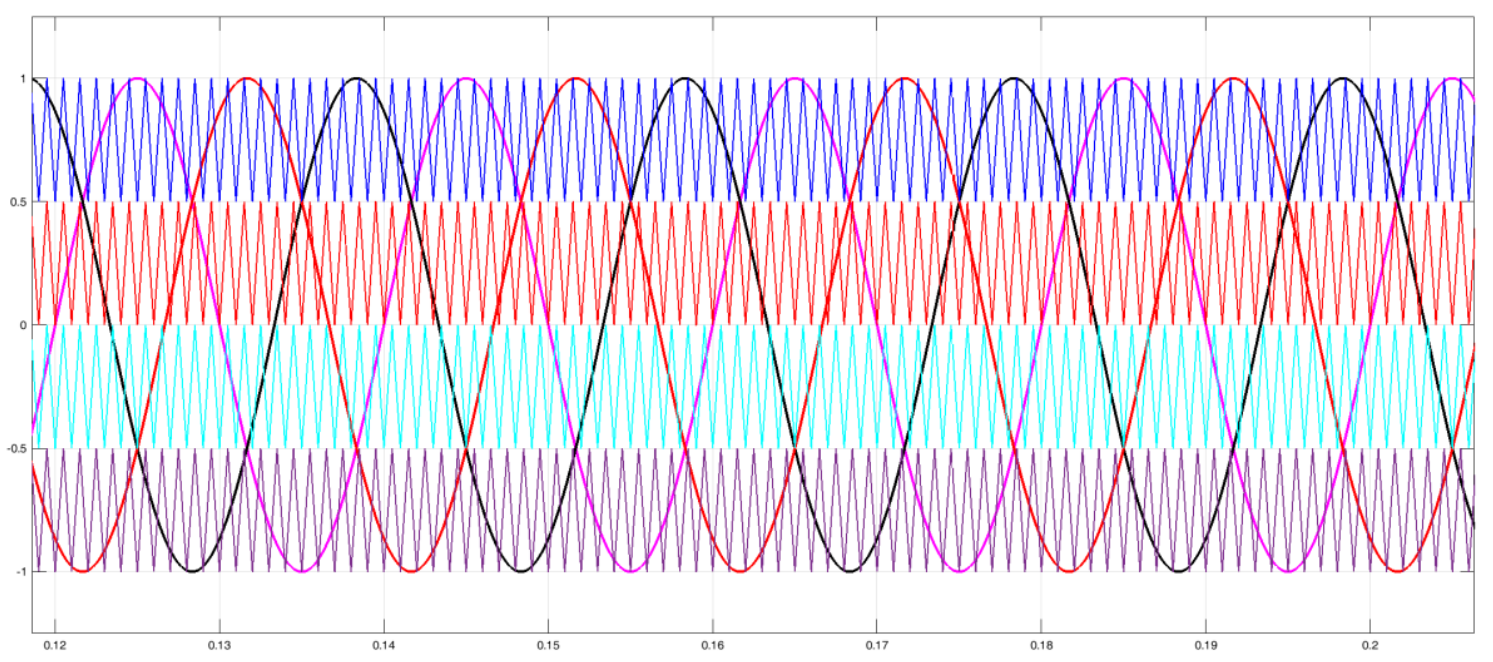

Fig. 2. Comparison of the carrier signal with the reference signal
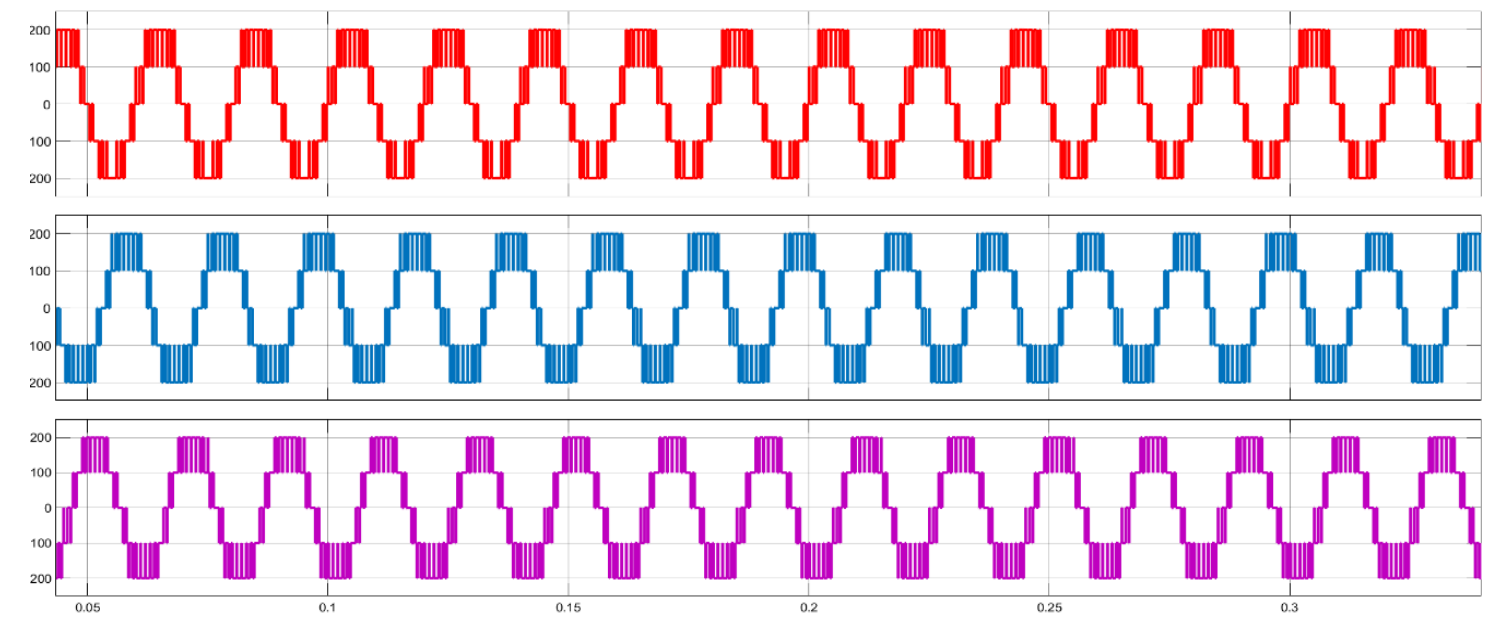

Fig. 3. Dynamics of the output voltages of the Five-level, three-phase inverter
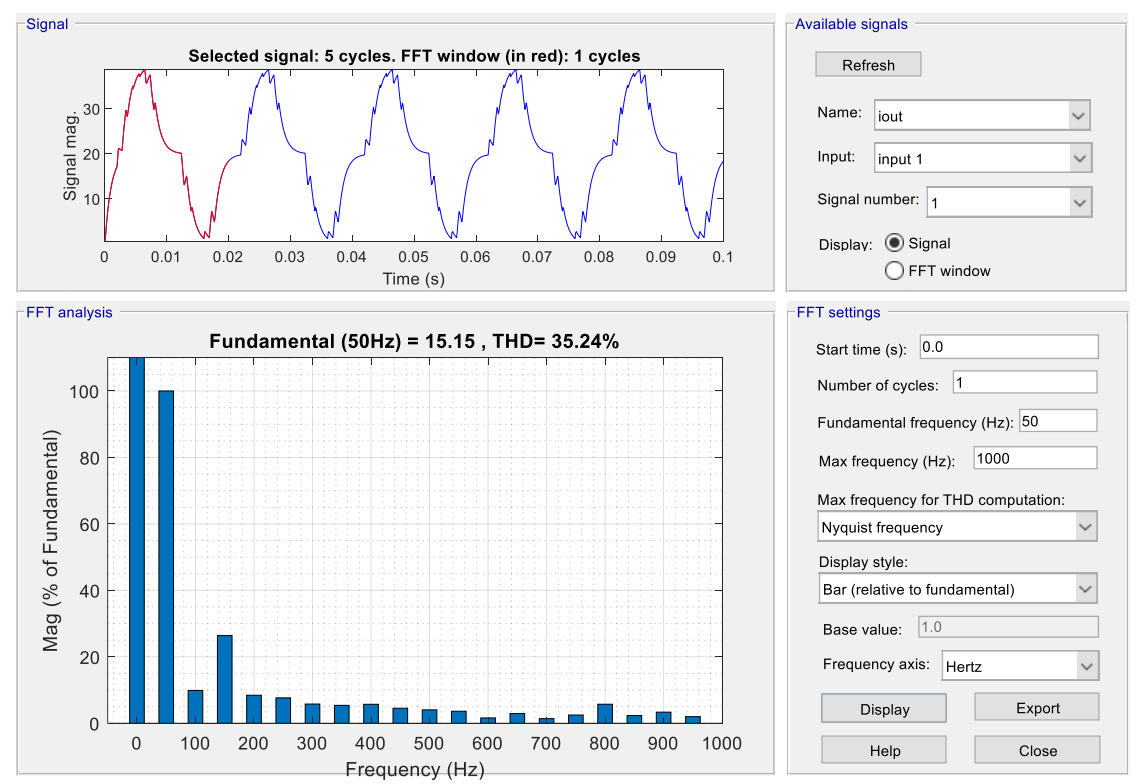

Fig. 4. Depiction of the Fast Fourier Transform analysis 
The motor dynamics was evaluated when a load torque of $3 \mathrm{~N}-\mathrm{m}$ was applied. The observed currents were low, which transmute to high efficiency as a result of low losses. The motor started and synchronized in less than $0.2 \mathrm{~ms}$, and the load had no effect on the rotor speed, as depicted in Fig. 5. The electromagnetic torque of the motor was zero immediately after the motor synchronized. Fig. 6 is a comparison between the stator current of the proposed model and the conventional PWM motor-fed.
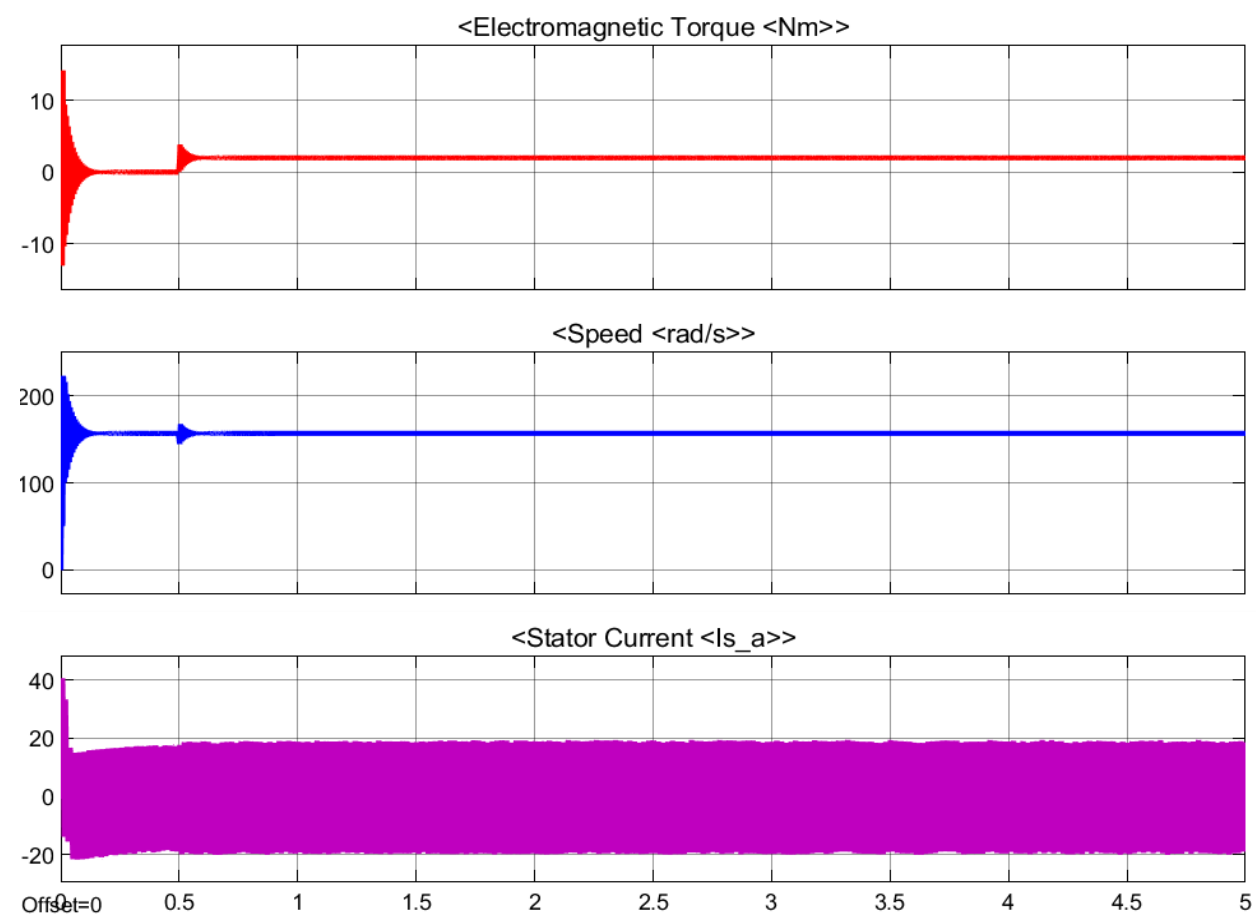

Fig. 5. Electromagnetic torque, rotor speed and Phase - A stator current

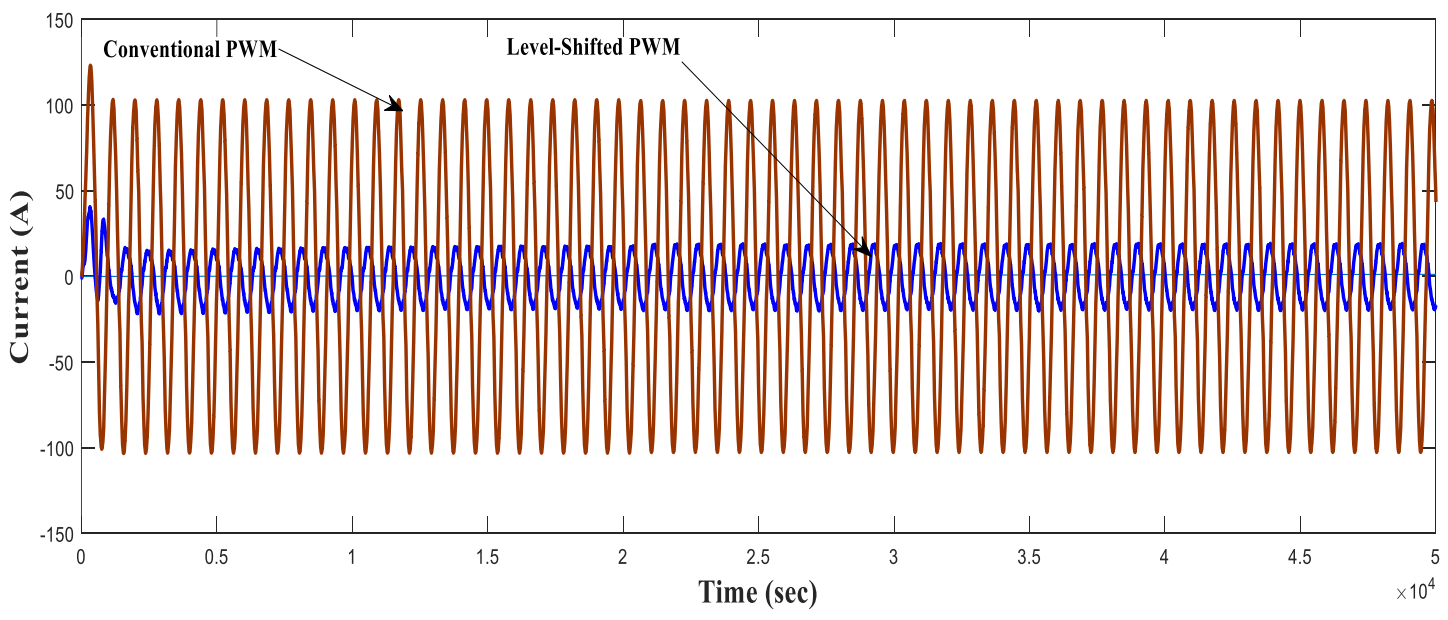

Fig. 6. Dynamics of the Stator current of the proposed model and conventional PWM

\section{Conclusion and Future Work}

A numerical study of a five-level inverter fed PMSM via co-simulation using in-phase disposition PWM techniques as the control strategies were proposed in this paper. The ANSYS MAXWELL electromagnetic suite provided the numerical simulation environment without the need to build a prototype. The effectiveness of the control strategy confirmed that the method minimizes the THD in the inverter circuit and eliminates the torque ripples of the PMSM even 
as the efficiency is enhanced. The stator current was relatively low when compared to those obtained in conventional motors. The performance of the proposed model demonstrates its usefulness in EV and robot manufacturing. The future work will be focused on how to extend the frontiers of the dynamics of the PMSM generated using the proposed method to the realm of chaos theory.

Funding: This research received no external funding

Conflicts of Interest: The authors declare no conflict of interest.

\section{References}

[1] E. Agamloh, A. von Jouanne, and A. Yokochi, "An overview of electric machine trends in modern electric vehicles," Machines, vol. 8, no. 2, p. 16pp, 2020. https://doi.org/10.3390/machines8020020

[2] I. Batarseh and A. Harb, Power Electronics: Circuit Analysis and Design, 2nd ed. Switzerland: Springer, 2018. https://doi.org/10.1007/978-3-319-68366-9

[3] N. B. Kumar, T. C. A. Kumar, and H. Arshad, "Design and analysis of different multi-level inverter topologies for single phase drive," Turkish J. Comput. Math. Educ., vol. 12, no. 10, pp. 4104-4117, 2021. https://turcomat.org/index.php/turkbilmat/article/view/5123

[4] G. Kibria, S. Islam, and A. K. Paul, "Comparative analysis of phase disposed carrier wave modulation for asymmetric three phase," in 2021 International Conference on Automation, Control $\begin{array}{llllll}\text { and } & \text { Mechatronics } & \text { for } & \text { Industry } & 4.0 & \text { (ACMI), }\end{array}$ https://doi.org/10.1109/ACMI53878.2021.9528211

[5] J. Pollefliet, Power Electronics: Drive Technology and Motion Control. Netherland: Elsevier, 2018.

[6] B. N. C. V. Chakravarthi, P. Naveen, S. Pragaspathy, and V. S. N. N. Raju, "Performance of Induction Motor with hybrid Multi level inverter for Electric vehicles," in Proceedings of the International Conference on Artificial Intelligence and Smart Systems (ICAIS-2021), 2021, pp. 1474-1478. https://doi.org/10.1109/ICAIS50930.2021.9395885

[7] R. Jyothi, T. H., R. K. Uma, and R. Jayapal, "Machine learning based multi class fault diagnosis tool for voltage source inverter driven induction motor," Int. J. Power Electron. Drive Syst., vol. 12, no. 2, pp. 1205-1215. https://doi.org/10.11591/ijpeds.v12.i2.pp1205-1215

[8] M. Rasheduzzaman and B. D. Poria Fajri , Jonathan Kimball, "Modeling, Analysis, and Control Design of a Single-Stage Boost Inverter," Energies, vol. 14, no. 4098, pp. 2-29, 2021. https://doi.org/10.3390/en14144098

[9] O. Tola and E. A. Umoh, "Modeling and analysis of a permanent magnet synchronous generator dedicated to wind energy conversion," in 2nd International Engineering Conference (IEC 2017), 2017, pp. 216-225. http://repository.futminna.edu.ng:8080/jspui/handle/123456789/6974

[10] G. Artetxe, D. Caballero, B. Prieto, M. Martinez-Iturralde, and I. Elosegui, "Eliminating rare earth permanent magnets on low-speed high-torque machines: A performance and cost comparison of synchronous reluctance machines, ferrite permanent magnet-synchronous reluctance machines and permanent magnet synchronous machines for a dire," IET Electr. Power Appl., pp. 1-9, 2020. https://doi.org/10.1049/elp2.12032

[11] Y. Sun, W. Zhao, J. Ji, J. Zheng, and X. Song, "Effect of phase shift on inductance and short-Circuit current in dual three-phase 48-slot/22-pole permanent-magnet machines," IEEE Trans. Ind. Electron., vol. 69, no. 2, pp. 1135-1145, 2022. https://doi.org/10.1109/TIE.2021.3059546

[12] E. A. Umoh, O. J. Ushie, and O. J. Tola, "Robot-Chaos Interaction," in 12th International Conference and Exhibition on Power and Telecommunications (ICEPT 2016), 2016, pp. 155-164. https://www.researchgate.net/publication/309126949

[13] E. A. Umoh and 0. J. Tola, "Electronic circuit realization and adaptive control of a chaotic permanent magnet synchronous motor," in 2nd International Engineering Conference (IEC 2017), 2017, pp. 395-404. http://repository.futminna.edu.ng:8080/jspui/handle/123456789/6857

[14] E. A. Umoh and T. Wudil, "Engineering Applications of Chaos," in 12th International Conference and 
Exhibition on Power and Telecommunications (ICEPT 2016), 2016, pp. 39-49. https://www.researchgate.net/publication/309175856

[15] M. Torrent, J. I. Perat, and J. A. Jiménez, "Permanent magnet synchronous motor with different rotor structures for traction motor in high speed trains," Energies, vol. 11, no. 6, pp. 1-17, 2018. https://doi.org/10.3390/en11061549

[16] A. Bughneda, M. Salem, A. Richelli, D. Ishak, and S. Alatai, "Review of multilevel inverters for PV energy system applications,” Energies, vol. 14, no. 6, pp. 1-23, 2021. https://doi.org/10.3390/en14061585

[17] R. Sarker, A. Datta, and S. Debnath, "An Improved multicarrier PWM (MCPWM) technique with a new harmonic mitigation strategy for cascaded H-Bridge multilevel inverter Applications," IEEE Trans. Ind. Informatics, vol. 1551, no. 3203, pp. 1-10, 2021. https: //doi.org/10.1109/TII.2021.3087458

[18] J. Pragya and S. P. Deshmukh, "Design of three phase five-level cascaded H- Bridge inverter with boost converter," Int. J. Electron., vol. 20, no. 1, pp. 1-36, 2020. https://doi.org/10.1080/00207217.2020.1818297

[19] I. E. Tashiwa, G. D. Dung, and B. S. Adole, "Review of Multilevel Inverters and Their Control Techniques," Eur. J. Eng. Res. Sci., vol. 5, no. 6, pp. 659-664, 2020. https://doi.org/10.24018/ejers.2020.5.6.1707

[20] D. Subramanian and R. Rasheed, "Five Level Cascaded H-Bridge Multilevel Inverter Using Multicarrier Pulse Width Modulation Technique," Int. J. Eng. Innov. Technol., vol. 3, no. 1, pp. 438441, 2013. https://www.ijeit.com/Vol\%203/Issue\%201/IJEIT1412201307_81.pdf

[21] S. Swathy, N. Niveditha, and K. S. C. Mauryan, "Design of five-level cascaded H-Bridge multilevel inverter," Innov. Electr. Electron. Eng. Lect. Notes Electr. Eng., pp. 65-80, 2020. https://doi.org/10.1007/978-981-15-2256-7_7

[22] K. V. Priya and A. Aswini, "Simulation of five-level cascaded H-bridge multilevel inverter with and without OTT filter," Int. J. Adv. Res. Electr. Electron. Instrum. Eng., vol. 5, no. 2, pp. 667-673, 2016. https://www.ijareeie.com/upload/2016/february/3_Simulation.pdf

[23] Y. Adem, "Design and simulation of single-phase five-level symmetrical cascaded H-bridge multilevel inverter with reduced number of switches," J. Electr. Electron. Syst., vol. 07, no. 04, 2018. https://doi.org/10.4172/2332-0796.1000281

[24] C. Kannan, N. K. Mohanty, and R. Selvarasu, "A new topology for cascaded H-bridge multilevel inverter with PI and Fuzzy control," in Energy Procedia, 2017, vol. 117, pp. 917-926. https://doi.org/10.1016/j.egypro.2017.05.211

[25] K. Shende, "Five level cascaded H-bridge multilevel inverter using pulse width modulation, inphase and alternate phase opposition deposition techniques," Int. J. Eng. Res., vol. 6, no. 2, pp. 495499, 2018. https://www.ijedr.org/papers/IJEDR1802086.pdf

[26] M. Mareeswari, K. Ramalakshmi, A. Saranya, and B. N. Hamitha, "Transformerless MOSFET inverter for grid-tied photovoltaic system," Int. J. Adv. Res. Comput. Commun. Eng., vol. 6, no. 3, 2016. https://doi.org/10.17148/IJARCCE.2017.63146

[27] V. Viswanathan and J. Seenithangom, "Commutation Torque Ripple Reduction in the BLDC Motor Using Modified SEPIC and Three-Level NPC Inverter," IEEE Trans. Power Electron., vol. 33, no. 1, pp. 535-546, 2018. https://doi.org/10.1109/TPEL.2017.2671400

[28] S. Jayaprakasan, S. Ashok, and R. Ramchand, "Current error space vector based hysteresis controller for VSI-fed PMSM drive," IEEE Trans. Power Electron., vol. 35, no. 10, pp. 10690-10699, 2020. https://doi.org/10.1109/TPEL.2020.2977581

[29] A. Balashanmugham and M. Maheswaran, "Permanent magnet synchronous machine drives," Appl. Electromechanical Devices Mach. Electr. Mobil. Solut., IntechOpen, 2020. https://doi.org/10.5772/intechopen.88597

[30] M. M. Zaid, M. U. Aslam, M. Sibtain, S. Hasnain, and J.-S. Ro, “Analytical modeling-based optimal design of multilayered and multisegmented D-type interior permanent magnet synchronous motor," Int. Trans. Electr. Energy Syst., vol. 31, no. 5, p. e12876, 2021. https://doi.org/10.1002/2050-7038.12876 